\title{
The Role of Social Capital in Labour-Related Migrations: the Polish Example
}

\section{Justyna Łukaszewska-Bezulska ${ }^{1}$ (])}

Published online: 3 September 2020

(C) The Author(s) 2020

\begin{abstract}
This article addresses the relationships between international labour-related migrations and social capital in two ethnically heterogeneous local communities, outstanding by their inhabitants' high degree of spatial mobility. On the basis of the observations performed and in-depth interviews with migrants and experts, social networks built by the inhabitants were analysed, with particular attention paid to migration networks, and the meaning and role of social capital in the inhabitants of cultural borderlands' migrations, especially in the areas of migrants' lives such as job seeking, living together and dealing with difficulties, were discussed. It has been demonstrated that the international labour-related migrations influence the quality and type of social capital present in the ethnically heterogeneous local communities at cultural borderlands, although the direction and force of this impact are not equivocal and depend most of all on the strength and quality of primary ties in the migrants' community of origin, i.e. if the community was rich in the social capital resources, migrations may contribute to its growth, while for communities deficient in this resource, migrations may cause its continued diminishing.
\end{abstract}

Keywords Migration $\cdot$ Migration networks $\cdot$ Ethnic minorities $\cdot$ Social capital

\section{Introduction}

Local communities have been the subject of sociological analysis since its inception. This topic was dealt with by, among others, classics such as F. Tönnies (1887), E. Durkheim (1893) and R. Park (1929). Nevertheless, there are still areas that require indepth scientific analysis. One of these areas is the interaction between international economic migrations and social capital, especially at cultural borderlands. According to

Justyna Łukaszewska-Bezulska

j.lukaszewska@uw.edu.pl

1 Faculty of Political Science and International Studies, University of Warsaw, Krakowskie

Przedmieście Str. 26/28, 00-927 Warsaw, Poland 
the researchers, many sociological aspects of migration cannot be captured except through the study of local communities. It is not only the intensity of emigration in different localities that varies, but also its types (Chałasinski 1936). With regard to the above words, the influence of international labour migrations on the formation and the shape of local social capital on cultural borderlands have been made the subject of the article. The key objective of this paper will be to demonstrate mutual interactions between spatial mobility of a population and social capital. The fact that the analyses will be conducted on the example of culturally diverse communities will make it possible to identify different types of the studied resource and its imponderables.

The issue of migration is very important for Poland. Since the opening of the labour market following Poland joining the European Union, Poland experienced a mass migration, which made Poland a typical immigration country and caused changes in many areas of social life: not only practices but also norms, beliefs and values changed (White et al. 2018, 2). At the end of 2018, around 2.5 million Poles were temporarily abroad, most in Germany (706,000), Great Britain $(695,000)$, the Netherlands $(123,000)$ and Ireland $(113,000)$ (Główny Urząd Statystyczny 2019). The demographic situation has changed in recent years, mainly as a result of the arrival of Ukrainian citizens. Poland becomes an emigration and immigration country now.

Empirical research that constitutes the basis of the article was conducted in two Polish localities of Podlaskie (Siemiatycze) and Opolskie (Leśnica) voivodeships. ${ }^{1}$ These regions stand out against a background of exceptionally high ethnic ${ }^{2}$ diversity and the degree of intensity of migration abroad. Based on the conducted observations and in-depth interviews with migrants and experts, the degree of integration and social networks built by the inhabitants, with particular emphasis on migration networks, will be analysed. The aim of the analyses was also to determine the scale of cooperation between residents during their stay abroad, in particular at the stage of planning the trip and during their search for work, housing and during difficult life situations.

At the beginning of the research, it was assumed that foreign labour migrations influence the quality and type of social capital present in ethnically diverse local

\footnotetext{
${ }^{1}$ Other names: Podlasie and Opolszczyzna

${ }^{2}$ The characteristic feature of Podlasie is therefore the multilevel national and religious self-authentication. The population of this region is characterised by a considerable diversity of confessions. As elsewhere in Poland, Roman Catholic religion prevails there (1.1 million believers - almost $72 \%$ ), yet the percentage of Catholics is significantly lower than in the whole country (97.8\%). A large group in Podlasie are Orthodox believers, who constitute over $27 \%$ of the population of the Podlaskie Voivodeship and only $1.5 \%$ of the population of Poland (Główny Urząd Statystyczny 2015; Urząd Statystyczny w Białymstoku 2015). At the same time, in Podlaskie Voivodeship, apart from Polish nationality ( $92 \%$ of the population), Belarusian (3\%), Lithuanian $(0.39 \%)$ and Ukrainian $(0.18 \%)$ were the most frequently indicated. It should be stressed that Podlasie is home to over $85 \%$ of all people who declared themselves a Belarusian national as first choice in the last census (Urząd Statystyczny w Białymstoku 2013). A particular trait of the Opolskie voivodeship, in turn, is that this region is inhabited by a population originating from different historical, civic and cultural traditions. The voivodeship is inhabited by the so-called indigenous population declaring German or Silesian nationality and the Polish population who came to the Opole region after World War II mainly from the areas lost to the USSR. The results of the last census indicate that the majority of the inhabitants of the Opolskie Voivodeship are of homogeneous Polish nationality and include 822,000 people, which constitutes $80.9 \%$ of the total population of the voivodeship. Meanwhile, for the whole country, the percentage is $93.88 \%$. The Opole region is also distinguished from the rest of Poland by a significantly lower percentage of the population declaring Polish national identity (only Polish and combined) $-86.8 \%$, while for the whole country, it amounts to $96.07 \%$. Moreover, of all persons declaring exclusively German national identity, nearly $65 \%$ lives in the Opolskie Voivodeship (Urząd Statystyczny w Opolu 2013).
} 
communities on cultural borders. It was also assumed that in the case of the population of Podlasie, emigration and joint work and housing and the need to cope with difficult situations, in particular, favour the establishment of close contacts between people of different national origins, coming from the same local communities, which in turn contribute to the growth of multiculturalism in its axio-normative understanding. On the other hand, in the Opole region, as a consequence of economic migration, the ethnic and cultural divisions between indigenous and incoming populations are being consolidated. It was also assumed that the divisions between the incoming and outgoing populations in the Opolskie voivodeship have a historical basis and result, among other things, from more favourable regulations for people of German origin, functioning in the past in the German law, especially regarding access to the labour market. It was also assumed that differences in the types of social capital characteristic to the studied local communities are largely due to the differently shaped migration networks: in the Opole region, inbound and local population representatives depart separately, to different places; they also perceive their trips differently: the locals go "to theirs" and the inbound population go "for work". In Podlasie, in turn, persons of different ethnic origins migrate and then work together and are perceived by the receiving community in the same way. In consequence, due to economic migrations, bonding capital develops in Podlasie and bridging capital in Opolskie.

\section{Theoretical Background}

Social capital is a multidimensional phenomenon that can be discussed at various levels, which can be observed, for example, through a review of how this concept is used in migration research. This category allows multilevel analyses to be carried out; as it concerns relations between individuals and groups, it also allows the study of the coupling between the two dimensions (Łukaszewska-Bezulska 2014). This aspect is underlined, among others, by T. Faist, who believes that social capital and networks are the link between the micro and macro levels and determine the nature of the social space, the context in which migration takes place (Faist 1997). As a result, it was necessary to analyse social capital in a minimum of three perspectives: local environment/ neighbourhood capital, ethnic diaspora capital and the individual capital of the subject (migrant). The subject of research may be both how the ownership or lack of social capital by an individual or community affects the level of mobility and how migration affects the level and quality of social capital of a community. Research also shows that there may be specific forms of cultural and social capitals that are only available to migrants as a consequence of their being migrants (Wahlbeck and Fortelius 2019).

D. Massey calls social capital the grease and fuel of migration (Massey 1999). The quality of social capital depends on two factors: the strength and type of bonds tying an individual to others and this individual's migration experience. According to researchers, the importance of networks and social capital is decreasing with subsequent migrations undertaken by a person, and the role of the individual in the network of connections is changing: from the "recipient" of resources, he becomes their "donor". Social capital is particularly important when immigrants take up their first job (Rey et al. 2019). At the same time, it should be remembered that in the case of less developed countries, migration is associated with high transactional costs related to the need to obtain information, for example, and the lack of efficient markets is 
compensated for by additional institutions, such as standards, customs and value system, which in effect lead to the creation of a kind of stream connecting the sending and receiving country of migrants (Guilmoto and Sandron 2001). This situation corresponds to the definition of the so-called transnational social space. Potential migrants belong to social structures, i.e. migration systems that bind them to other individuals, groups and a range of other social structures (D'Ambrosio et al. 2019), (Faist 2000). The accumulation and investment of social capital takes place throughout the migratory trajectory - starting well before leaving - and is embedded in a transnational social space (Glorius 2019).

This issue is closely related to the issue of migration networks, which are described by P. Sztompka as an interesting variety of complex geometry of trust (Sztompka 2007, 261). According to D. Massey, the author of cumulative causation theory, migration networks are sets of interpersonal ties that link migrants, former migrants, and nonmigrants in origin and destination areas through the bonds of kinship, friendship and shared community origin (Massey et al. 1993). These are not the networks themselves that fuel the migration process, but a specific, additional quality (that is, the social capital), established and accumulated through them. This capital is the sum of potential and current resources to which the entity or group has access and which it accumulates as a consequence of having a permanent knowledge network (Koltai et al. 2020; Massey and Zenteno 1999).

Local social networks, including migration networks in particular, are primarily the means of support, a way to deal with the lack of presence of those living abroad. They also serve as a channel for increasing resources in the country of origin. From the point of view of the country of destination, the networks constitute a key resource in migrant adaptation, especially in the areas such as seeking work or seeking a place to live. At the same time, the authors underline that the relationships based on ethnic ties offer a varied adaptation context, according to the individual's structural position in the ethnic network. Ties to people who already have some migration experience enable the individual to access the resources that might appear useful in the future, when making the decision to travel abroad. This statement embodies the social capital hypothesis of migration (Nowotny and Pennerstorfer 2019), (Garip 2008).

R. Putnam observed that residential stability is strongly correlated with social participation, as it takes time for a mobile individual to put down new roots (Putnam 2008, 343). According to R. Putnam, people who expect to move in the next five years are 20-25 percent less likely to attend church, attend club meetings, volunteer, or work on community projects than those who expect to stay put (Putnam 2008, 343). Therefore, according to R. Putnam, social mobility undermines both civic participation and community-based social capital. Similar conclusions can be reached with the "insider advantages approach" theory. According to its authors, a certain level of immobility is crucial to the accumulation of social capital and to the sense of roots in the community (Fischer et al. 1998). Labour migration contributes to the loosening of social ties, which in turn may also affect the health of the residents of a particular local community (du Plooy et al. 2020).

From an individual's perspective, people are much less likely to move to a community where the average level of social capital is lower than their own. A higher level of social capital in the community acts as a positive facilitator. Higher individual social capital is a negative migration predictor (Hotchkiss and Rupasingha 2018). 
Therefore, the migrant social capital therefore consists of two inseparable elements - the resources that facilitate the migration process and the links between the holders of these resources. However, it should be borne in mind that both links and resources can be of different nature, which has important practical implications, which will be discussed later in the article. A characteristic feature of social migration capital defined in this way is that it is substitutable, i.e. it can be replaced by other types of capital. At the same time, a lack of knowledge or resources can be made up for with the capital one owns. Migrants often convert initial social capital into other types of capital.

\section{Study Methodology}

S. Baron, J. Field and T. Schuller observe that there exists a set of terms that definitions of social capital present in the literature refer to, yet these terms are operationalised in so many different ways that we should ask ourselves whether social capital is a singular, separate (Baron et al. 2000). In this paper, the basic definition of R. Putnam, according to which social capital refers to features of society's organization such as trust, norms and relationships that can increase the efficiency of society by facilitating coordinated actions, is considered fundamental (Putnam et al. 1993, 258). In the undertaken research, social capital is treated as an important resource for the entire local community. The distinction between bonding and bridging capital, proposed by the same author, also plays an important role. Based on this definition, trust, norms, integration levels, linkages and the role of networks (especially migration networks) have been identified as the key elements of social capital (Fig. 1).

In the studies undertaken, the distinction between bonding and bridging social capital was important. The graphic below presents the indicators of both types of capital (Fig. 2). ${ }^{3}$

For the purpose of this article, we adopted S. Eisenstadt's definition of migration as a physical transition of an individual or a group from one society to another. This transition normally involves abandoning one social setting and entering another, and different one (Eisenstadt 1953), with the reservation that this entering into a new social setting is not permanent, final. On the other hand, the economic nature of migration results from the motive determining the departure. This paper will be focused primarily on temporary migrations.

On the other hand, the term "borderland" is defined after A. Sadowski as an area of mutual contact between representatives of two or more communities ethnically and culturally diverse.

The selection of the places of study was purposive: the selected places were to have a population that was greatly varied in terms of ethnicity and culture and experienced intense migration processes. The ethnic and cultural diversity of the inhabitants of the

\footnotetext{
${ }^{3}$ Description to the graphics:

Co-operation - a voluntary activity, both formalised and informal, for the benefit of the local community in order to achieve common goals.

Close relations with neighbours - frequent conversations, meetings and visits.

Inter-ethnic character of the organization - acting for the benefit of the local community in its broadest sense and supporting multiculturalism.

Living together (or willingness to do so) applies only where there was a possibility to choose the place of residence and the persons living together.
} 


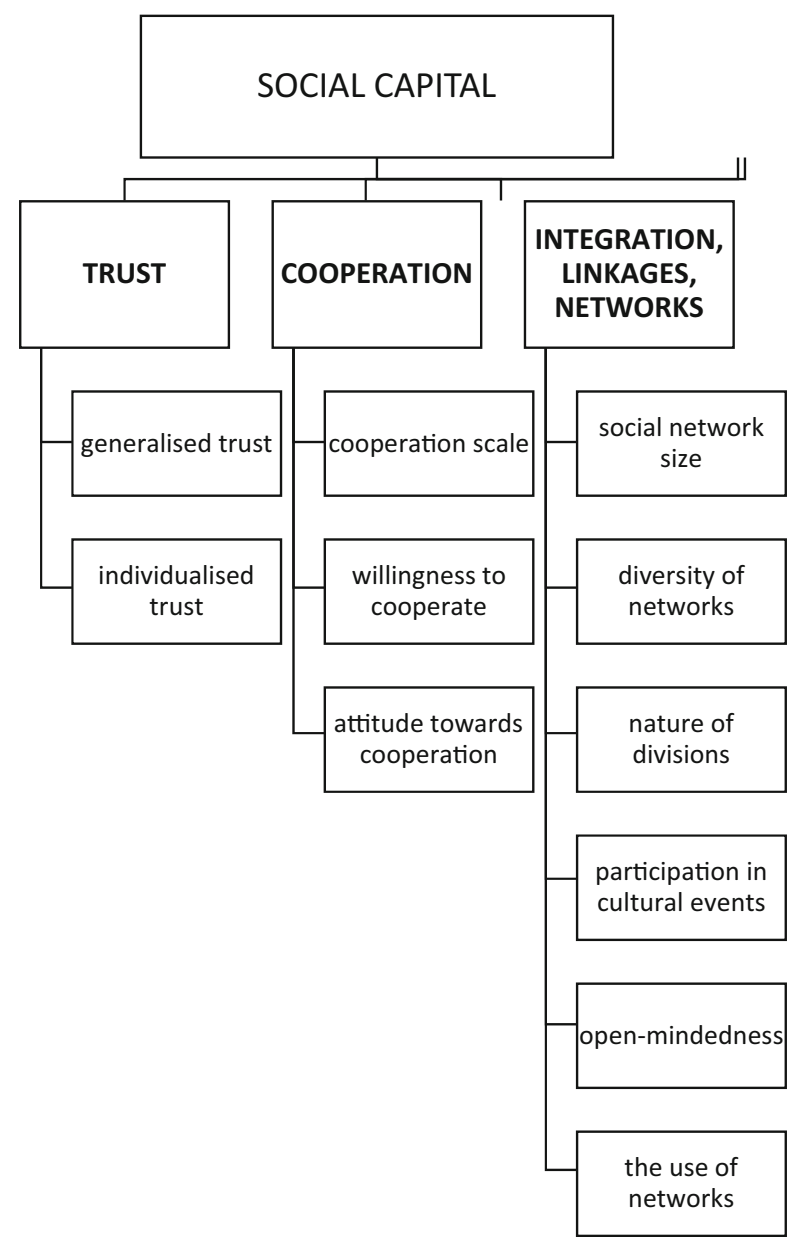

Fig. 1 Operationalisation of the term "social capital". Source: own work

Opole region concerned their nationality ${ }^{4}$ and was determined on the basis of the results of the National Census. In the case of Podlasie, confessional diversity was taken into account and estimated on the basis of literature analysis and statistics of Catholic and Orthodox churches. The strength of spatial mobility was defined using the Central Statistical Office data on the extent of temporary migrations abroad for over 3 months.

Techniques of non-participant observation and scenario-based individual in-depth interviews with experts ${ }^{5}$ and migrants ${ }^{6}$ were used to investigate local social capital and its impact on international labour migrations. Experts were people who knew the specificity of local communities or who dealt with social problems due to their

\footnotetext{
${ }^{4}$ The perception of the ethnic and cultural diversity of the Opole region's population only in national categories is a big simplification, but it was necessary due to the nature of the National General Census data, which are the only comprehensive statistical elaboration of this issue at the level of municipalities.

${ }^{5}$ Interviews with respondents from Podlasie are coded as PX and from Opole, OX, where X is the number of the respondent.

${ }^{6}$ Interviews with experts from Podlasie are coded as EPX and EOX for the Opole region, where $\mathrm{X}$ is the number of the respondent.
} 


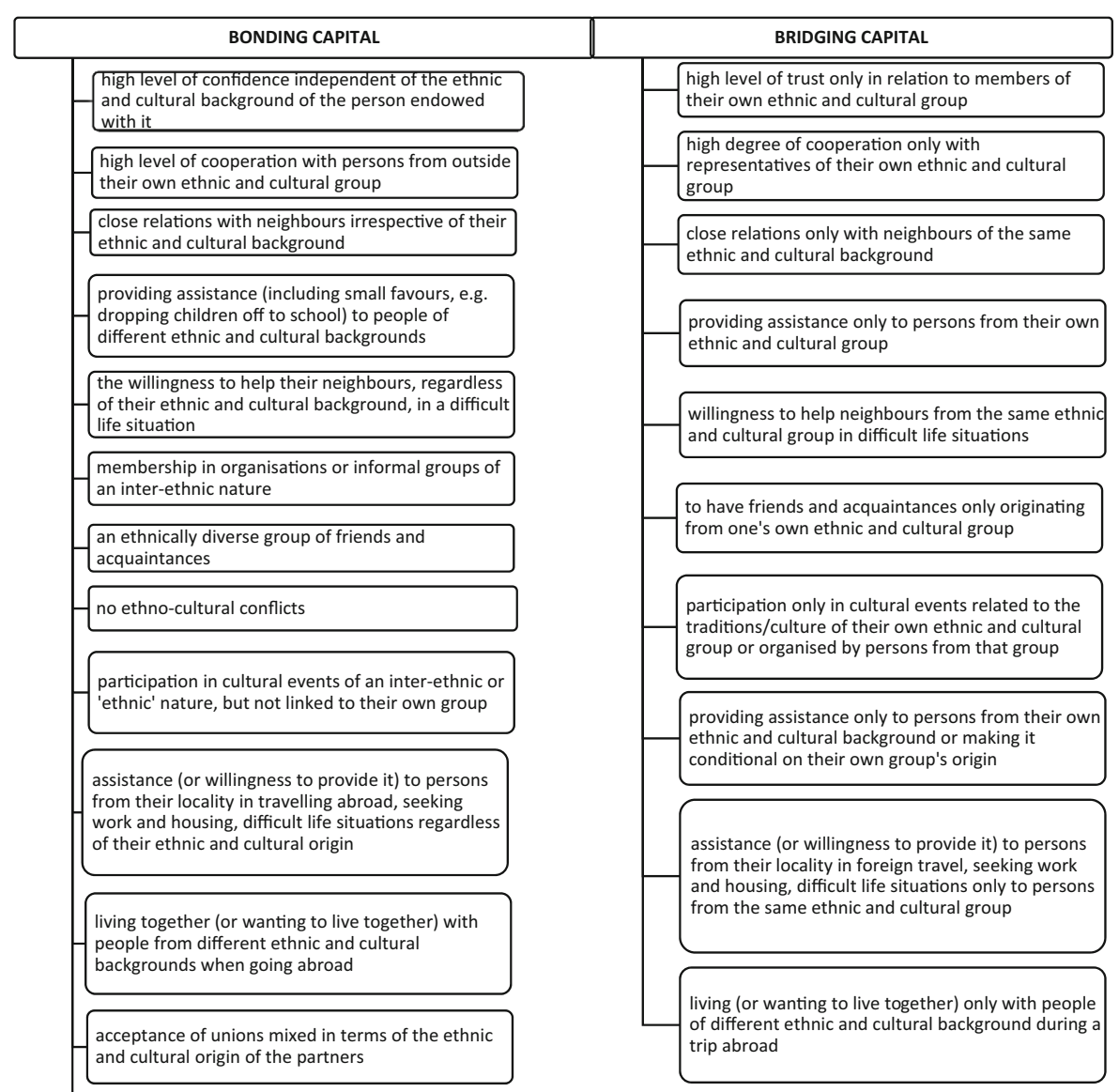

the same way of assessing the conduct of people

from their own and from a different ethnic and

cultural group

Source: own work

Fig. 2 Indicators of bonding and bridging social capital in culturally diverse communities

professional duties, i.e. representatives of local authorities (mayor), non-governmental organisations and employees of the Social Welfare Centre. In turn, observations were made during local fairs and markets, at the bus station, during local holidays and celebrations. Potential respondents were also recruited there. In order to achieve maximum diversity of the sample (e.g. in terms of social activity, membership in organisations), the snowball method was abandoned.

The time of their completion was very important for the discussed study. In the case of the Opole region, it was necessary to conduct talks at weekends, and in Podlasie during the Christmas period, when migrants come home to see their families. 


\section{The Importance of Social Capital in a Migration Situation}

\section{Planning of Departure}

Migrations from both Podlasie and Opole regions are of a chain character and are based on the existence of strong migration networks. Their importance is particularly strong at the stage of trip planning and in the initial months of the trip.

Migrants from Podlasie region base their foreign trips on the existing networks and connections. This is all the easier since, regardless of their ethnic origin and religion, they migrate to the same places (most often to Belgium). All the migrants from the Podlaskie voivodeship declared that when planning a trip abroad, they consulted family members and friends who had already had migration experience and who already had some connections, because someone had left earlier and is going to see a given, particular person. And he's got the accommodation there and the first steps, and they'll help him with work. Sometimes they come and really appreciate it, much that they did not even expect to be received this way (PE3).

In the case of migration of autochthonous population of the Opole region, migration networks were particularly important in the initial period of foreign emigration from this region. Older respondents emphasised that when going to Germany, they were relying on the knowledge of people who were the first to emigrate. They most often contacted them in order to obtain information about everyday life and job opportunities. In case of the contemporary migration of indigenous people from Opole region, the importance of migration networks is decreasing. This is especially illustrated by the statements of the youngest respondents, who declare that in their environment, the knowledge on issues related to travel is common and that no special connections are necessary to have access to it. It should also be noted that the youngest respondents are more willing to use specialised agencies for recruitment than their friends or family. In the case of migrant populations, the importance of migration networks is still important. People who have no previous experience of economic migration from Poland willingly take advice from more experienced people and turn to them for help in connection with the planned emigration. What is important, however, these requests are usually addressed to the representatives of their own group, and not to people coming from the immigrant population of the Opole region, who has much greater experience of travelling abroad, which confirms the lack of bonds and trust between the two groups.

Developed and strong migration networks, through which people going abroad look for information on living and working conditions abroad, have a positive impact on local social capital. Their importance is currently the most important for the group with the least migratory experience, i.e. the immigrant population of the Opole region. Although the value of migration networks is gradually decreasing, the social capital mediated by them still remains an important resource for the local community, as shown by the example of autochthons from the Opolskie voivodeship. In the case of Podlasie, joint foreign economic trips of people of different ethnic and cultural origins have a positive impact on the connecting social capital, while in the Opole region, due to the diversity of directions of movement, they contribute to the shaping of the connecting capital. 


\section{Housing Strategies}

Migration networks are also used after arrival in the destination country. They play a major role in the search. In this context, the respondents mentioned two situations, recommending their friends looking for a flat to people who want to rent one and looking for new tenants when they decide to leave the shared flat.

Respondents from both Podlasie and Opole regions often declared that during their trip abroad, they lived with other people from their home countries. In the case of the respondents from Podlasie region, the differences in housing habits are much smaller than in the case of people from the Opole region. The mechanism of chain migration is characteristic for the inhabitants of Siemiatycze, which then translates into their housing strategies. Respondents from Siemiatycze most often migrated to "someone", most often to their family and less often to friends who had previously gone abroad. Such a person provided them (at least during the first weeks of their stay) with accommodation, helped with renting or offered co-housing. A typical example of such a situation is the story of a son of one of the respondents, who lived with his friend for two weeks and then met a girl from his village, the one he came from, a friend who lived there and took him home. And that's where the two of them lived. Later he rented himself a large attic and lived there, the three of them. At the moment, he has an apartment and also lives with his son and a friend (P4). Another strategy is particularly characteristic of people who "brought in" their family members other than the spouse. Co-housing relatives or friends, apart from the possibility of quicker adaptation to new conditions (e.g. through faster access to various types of information) and a greater sense of security, is, above all, much cheaper. This factor was particularly important in the initial phase of migration, when the aim of the outgoing persons was primarily to "make money". Therefore, they tried to maximise their income by undertaking as many jobs as possible and at the same time minimising costs, e.g. by bringing some food products from home or renting the cheapest possible flats. One of the respondents says: Our mother-in-law sent us packages because she worked in PKS [translator's note: the Polish national bus communication company] Every week, everything from Poland. Fruits from Poland even. Bread nonstop (P5).

The respondents from Siemiatycze very often rented rooms in migrant flats. The respondents declared that the confessional criterion was not important for them when deciding on a common flat. The moment when a migrant leaf a shared flat is also interesting. Most often, it is the migrant who searches for a person to take her place. Most of all, this person must be trustworthy, not to expose other tenants to any issues, resulting most of all from the fact that their stay or employment are illegal.

The housing strategies of the respondents from the Opole region are partially different and depend mainly on two factors: their cultural and ethnic origin and their family situation. The representatives of indigenous population (but only men who have been migrating for a long time) are typically living together with other migrants who often come from the same locality and ethnic-cultural group (we had a four-room apartment for twenty people (OE3)). This may be due to several factors. First of all, dual citizenship gave the possibility to take up legal work abroad even before Poland's accession to the EU. So, since they were mainly people of indigenous origin, it was only natural that they lived together. This was also supported by the nature of their work, especially in agriculture and construction. Employed at one construction site or 
on a farm, they were often provided with a flat by their employer. Most often they were multiperson houses, barracks or multiroom apartments. In this case, the positive experiences connected with living together abroad are an important resource conducive to the creation of the bonding social capital among the indigenous inhabitants of the Opole region.

Housing strategies of spouses or couples have a different character. Even if during the initial period of their stay abroad they lived together with other people from the same locality or even with family members (e.g. parents or siblings), after the first months of their stay, they would decide to rent a separate flat. They justified their decision most often with the positive influence of separate living on marital relationships and the willingness to become independent.

The representatives of the migrant population most often migrate to places other than the indigenous population, so it is natural that the representatives of both groups do not live in the same place, so it is not conducive to the creation of the bridging capital in this group.

At the same time, the respondents stressed that a trip abroad had a negative impact on their relations with friends and acquaintances who do not have migration experience. They declared that they felt uprooted from the local community, they had fewer and fewer common topics to talk and at the same time they were less and less interested in what was happening in their hometown. Departures abroad had a negative impact on the strength of ties and relations between migrants and persons who remained in the country. As a result of their departure, emigrants gradually lose contact with the community of origin and the existing circle of acquaintances, and they also do not make acquaintances with the people who join this circle. One of the respondents, mentioning her return to the country, states: When I came back, it's just, when my sister told me about someone, I told her: God, I do not know half the people. This is seven years, however, taken from life (P3). Therefore, as far as Siemiatycze is concerned, in this aspect, it is not possible to indicate a clear direction of the relationship between migration and local social capital. Migrations abroad for economic reasons break the migrant out of their local communities and weaken ties with his or her existing friends but at the same time provide an opportunity to make new, lasting and meaningful acquaintances.

\section{Job Search}

Another situation in which migration networks play a very important role is that of the moment when jobs are sought. They are particularly important for the inhabitants of Podlasie. According to the researchers, the trips of Poles to Belgium were determined mainly by economic motives. The aim of the migrants from the studied groups is most of all to accumulate money; as a result, they try all the possible ways to acquire the best, i.e. best paid work. Because it is a key resource, information on it starts to come with a price. Job trading is considered one of the typical symptoms of migration networks at work. It is considered to be introduced by migrants from Podlasie, and in principle, it is only practised by them (Hirszfeld and Kaczmarczyk 2000, 35). This type of behaviour was also often mentioned by respondents from Siemiatycze. The vast majority of respondents claimed friends or family members who decided to go abroad earlier helped them find their first jobs. For example, one female respondent, when asked 
about her job search, declared: I'm telling you, it's about friends. Because my auntie is also there, and my mum, so you know... So, it went quickly (P3). Another one recalls: At the beginning, yes, my sister helped me, and later, we helped each other, somebody recommended you and that's how you got jobs. When it happened, when I had my week figured out, and for example, when one of my girlfriends, or someone in the family, needed hours, then I asked these people, that I cannot take it, but I can recommend someone and then I'd give these hours to my girlfriends (P6). For women migrants from this region work working as babysitters and house help, the so-called swaps, that is, two (or more) people working interchangeably for the same employer are a typical form of work. While one is working, the other one has time off and can return to her family. This form of employment requires strong trust between those who use it, as well as knowledge of other migrants (or potential migrants) who have would have agreed to work this way. Selling or lending work is also a common observance. For example, one of the female respondents recalled: No, I did not go as a shot in the dark. My mother-in-law once worked there and had some jobs she lent me for some time. And for the first time I even went there to replace her (P7).

Migrants from the Opole region also used the help of relatives and acquaintances to look for a job, thus using the resources of migration networks. This phenomenon was particularly important in the initial period of migration to Germany. Today, migration networks are used primarily by populations of immigrant origin, i.e. persons who have started relatively recently, but play a less important role in the case of the indigenous population. However, in the statements of representatives of both groups, there are voices indicating the important role of relatives and acquaintances when looking for work abroad. Such intermediation played a particularly important role in the initial migration of the autochthonic population. This situation was favourable both for employers, who thanks to expanding migration networks gained access to large resources of relatively cheap labour, and for potential employees, who could find employment that is reliable and paid much better than in the country of origin relatively quickly. It was often the case that several people from a given locality worked abroad in a particular company. A common experience of migration and employment in the same place strengthens existing ties and thus has a positive impact on the binding social capital. As mentioned by one of the respondents: In general, it was based on the fact that only Poles who lived in Germany for good worked in the company, so that the boss would have a base there, so that it seemed there were a few Germans, right? Other people who worked there were also from here, from the area, Wysoka, Leśnica, Polska Cerekiew, Koźle. And they all had to have double citizenship. I also talked a few people into it. I asked the boss if there would not be room to get in, right? So, I also got the job for two or three (O11). According to the respondents, currently, finding employment in Germany or Holland by the residents of Leśnica does not pose any problems and is even easier than looking for it in Poland. As one of the respondents says: How was I looking for a job abroad? It's not hard to find one here. Here you will call one, two, three friends, oh, and I already have a job (O9).

Having settled in a new place, migrants often "bring in" their next of kin and acquaintances, especially those from the same locality, and then help them find a place to live or work: it's just like that, for example, that someone needs a job, it's like that we exchanged and that's how we offered each other a job (P3). In this manner, the migration chain keeps growing. A similar mechanism occurs in the Opole region. 
Respondents often mentioned that they helped their relatives and friends find a job. Such support is taken for granted: Of course! Friends often called, I knew them, I knew that you can also recommend someone who is not irresponsible, so you also talked to your boss, they said that someone needs to, wants to work and that's all, that's how it worked. And if anyone wanted to, they'd come. It has happened more than once (O9). This form of job search was particularly important at a time when Poles could not, in principle, take up legal employment in EU countries. At that time, it became very important to have friends who helped the migrant find a job in the shadow economy. At present, it can be assumed that such intermediation will lose its importance. It can, in turn, be an advantage when looking for jobs requiring specific qualifications or when there is a high level of competition on the labour market. In the context of this paper, it is also worth noting that job search mediation in the shadow economy required a large amount of trust between all parties involved in the process, i.e. the employer, the potential employee and the job seeker. Thus, in a specific way, it contributed to the creation of specific social capital resources.

\section{Difficult Life Situations}

Migration networks are particularly important when faced with difficult life situations. They play an especially important role for the elderly and those who do not speak foreign languages. Knowing that they can count on the support of their next of kin is particularly important to them, especially in the event of an accident or illness, when they need to visit a doctor or stay in hospital. As one of the respondents noticed, when you go to a hospital, you need to know the language. There's got to be somebody, because they have these different systems. They're asking if you want a private procedure or a public one. You want a private one, then it turns out that it costs a five or six grand. That's what you have to pay for. There was an accident at my husband's construction site too, the guy cut his hand and they'd caught his muscles, and he says that he would rather not have the finger than pay in Euros. Because they are asking. If you do not know the language, this language barrier is still there (P4).

In the case of younger respondents, the importance of migration networks is decreasing. They are mainly replaced by human capital, especially foreign language skills and the ability to find one's way around and use foreign institutional infrastructure (e.g. knowing which institutions to go to in the event of a specific problem). Perhaps as European Union citizens, young immigrants are aware that they enjoy certain rights just as much as the citizens of the countries in which they work, so they are trying to make full use of them. Moreover, most of them have a regulated status on the labour market, so they do not have to worry that solving their problems will reveal that they, for example, work in the grey market. What is important, migrants from Podlasie declared that in the situation when someone asked them for help, as well as when they made such requests, the confession of the participants of this event did not have any meaning. The respondents also gave numerous examples of situations in which they helped adherents of other religions, as well as events in which they were helped. Therefore, it can be concluded that this fact is an important indicator of bridging social capital.

Among the respondents from Leśnica, assistance in difficult life situations was more often provided by persons belonging to an immigrant population group. It should be 
noted, however, that this was mainly due to the fact that they were the ones to whom the request for assistance was addressed and that the requesters also belonged to this group. The cases others turned to migrants with were mostly about job- and houseseeking support. At the same time, the representatives of the immigrant population had relatively often negative opinions about the compatriots staying abroad. For example, one of the respondents claimed that a Pole abroad is an enemy of another Pole. Why should anybody have it better? (O2). In turn, autochthons declared that in their local community, migrations are so common, that they are currently not associated with any difficulties, so there is no need to provide assistance to anyone. At the same time, the respondents claimed that if such a necessity appeared, they would certainly not deny their support to anyone. However, these statements are merely declaratory in nature. It is also worth noting the lack of cooperation and closer ties between the immigrant and indigenous population. Even beyond the borders of the country, they function in principle within their own group of origin, maintain divisions, do not support each other and do not create a wider community of "migrants from the Opole region".

\section{Conclusion}

Foreign economic migrations affect the quality and type of social capital present in ethnically diverse local communities on cultural borders. The direction of this interaction is not unambiguous, because also in this case, the "Matthew effect" (Merton 1968) is observed: if the community was rich in social capital, migration can contribute to its growth, while for communities poor in social capital, it can contribute to its further decline.

The conducted research indicates that in Podlasie, there is a potential for the development of bridging (inter-ethnic) social capital, while the indigenous population of the Opole region has significant resources of bonding capital and it is that resource that is multiplied thanks to migrations. Living and working together can help overcome stereotypes, develop an attitude of openness to different kinds of "difference" and foster closer ties between members of different communities (Fig. 3).

In case of the Podlasie residents, staying abroad fosters contacts between persons of various national origins and confessions, which, in consequence, contribute to the accumulation of multiculturalism in its axio-normative understanding. Residents of Podlaskie voivodeship of different ethnic origin leave and then work together and are perceived in the same way by the host community, which has a positive impact on relations between migrants, because the situation of departure leads to their equality, status similarity. In the case of Podlasie, we can talk about the creation of an "interethnic migrant community" - people from different ethnic and cultural backgrounds, from the same neighbourhood, coming together and working abroad. In turn, with regard to the population of the Opole region, the diversity of migration patterns of indigenous and inflow population is clear. They differ not only in their directions of travel but also in the factors motivating the decision to leave the country and determining the duration of the stay abroad, their attitude towards a possible return to their place of origin and the way in which migration networks are used. In case of the native inhabitants of the region, trips abroad for work are one of many factors strengthening the cohesion of the group and positively 


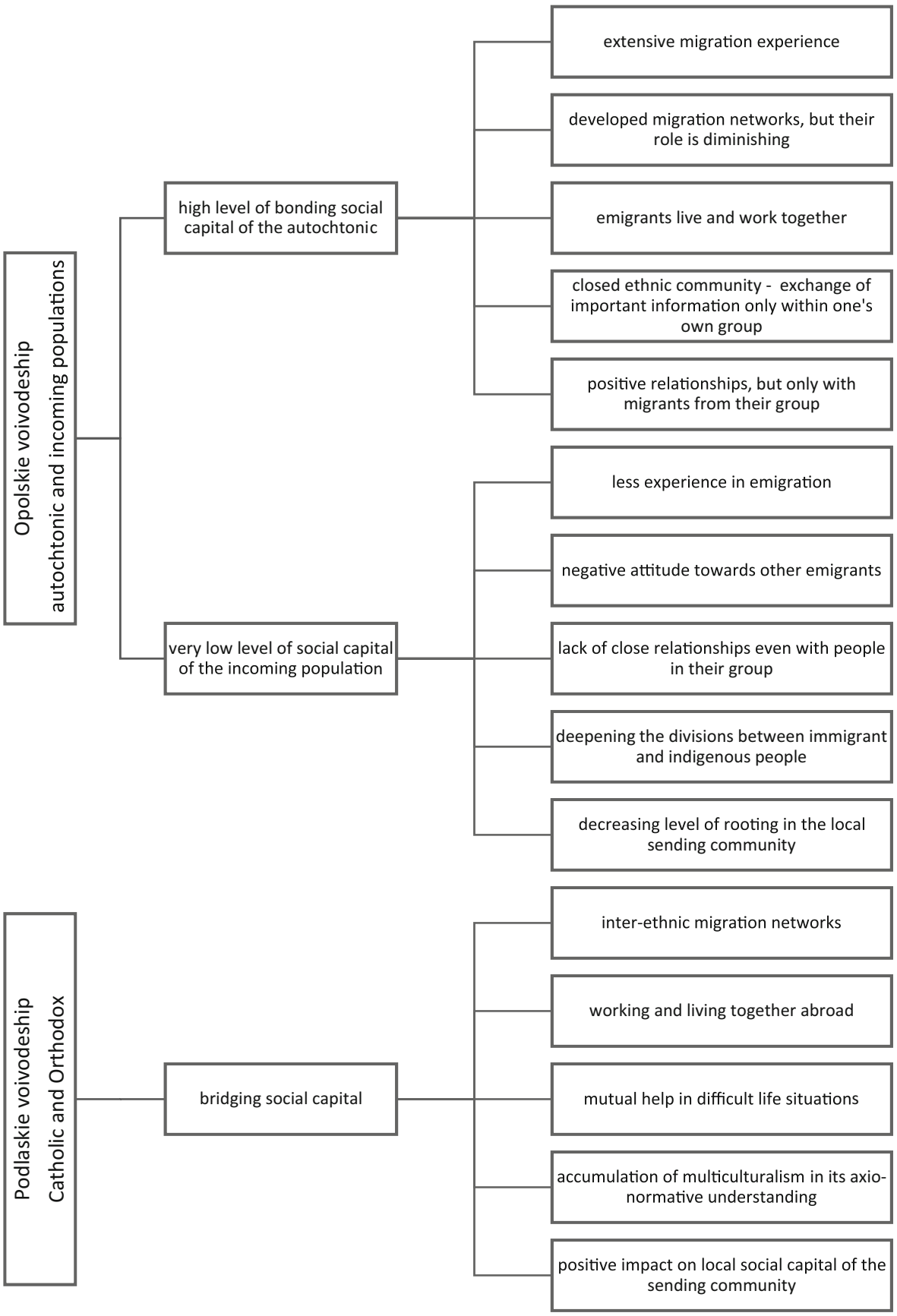

Fig. 3 The impact of migration on the local social capital in Podlaskie and Opolskie voivodeships

influencing its characteristic binding social capital. However, with regard to the immigrant population, it can be stated that the trips abroad further reduce their low degree of anchoring in the local community. 
In general, it can be stated that differences in the types of social capital in both analysed regions result from differently shaped migration networks: in the Opole region, Poles and Germans leave separately, to different places, and perceive their trips in a different way: Germans go "to theirs", Poles "for work". In the case of migration of people from Podlasie, it is also very important that people of different ethnic origins are perceived as "their own" during emigration, and these behaviours are continued after their return to Poland. Cooperation in finding a job abroad (especially exchange, sale or transfer of jobs) and especially co-residence of economic emigration in the country make the differences in religion or nationality less important, while the common experiences connected with travelling abroad become more and more important, and thus, the solidarity of one's own is built. Positive experiences connected with shared living and working abroad are an important resource conducive to the formation of bonding social capital among the indigenous inhabitants of the Opole region. It is worth pointing out here the role of the reciprocity standard (especially sustainable reciprocity), whose importance for social capital was pointed out, among others, by E. Ostrom (Ostrom 1990) and R. Putnam (Putnam et al. 1993) and which becomes a reality in the process of functioning of migration networks.

In the case of Opole region, the importance of the networks depends on the ethnic and cultural background of the migrants. For autochthons, they were particularly important in the initial period of trips, but today, they have been largely replaced by other elements of "migratory infrastructure". On the other hand, due to a relatively limited migration experience, the networks still serve to provide information, risk protection or an intermediary in searching for work and housing for the immigrant population. It is also important that, in principle, there are no connections between autochthonous and immigrant population networks. Edwards et al. (2001) prove that social capital can only come into play if the resources linked to the networks are directly available, ready to be used. In the case under consideration, only persons who are members of a specific migrant group have access to the network's resources. Thus, the migration networks existing in the Opole region only have an impact on bonding capital being created, while a lack of inter-ethnic migration networks removes them as carriers of bridging capital.

Migration networks continue to play an important role in shaping the patterns of migration from Podlasie, as well as being an important factor facilitating decisions on living and working abroad. Thanks to well-developed networks, people leaving the Podlaskie region have easier access to information not only on everyday life outside Poland but also on potential dangers associated with the trip. This makes potential migrants aware of the risks, allowing them to take measures to minimise their occurrence. The paradoxical importance of undeclared work for the trust mechanism is also worth pointing out. Black economy employment requires a large amount of trust between all sides of the process, i.e. the employer, the potential employee and the job seeker. It therefore contributes in a peculiar way to the emergence of specific social capital resources.

Very important topic is home country activities of the migrants. Here can be identified two different trends. Among the reasons for low organisational activity of Siemiatycze inhabitants, apart from the lack of time, foreign labour migrations are most often indicated. According to respondents, they uproot residents from their community and make them not interested in local problems. Even if they often visit the country, 
they devote their free time primarily to family. Migrants after a certain period of stay abroad no longer feel in Siemiatycze like "at home", not only because they know less and less about local matters, but also because of the fact that people who remained in the area were treated they are as someone "from the outside", and therefore, they cease to see the sense of activity, especially of a formal nature.

Migrants from autochthonous population of the Opole region treat activity in such organisations as their duty, an expression of local patriotism, especially if they have a good financial situation. From their responses, it can be concluded that by engaging after returning from a trip abroad, they try to make up for lost time, to make up for forced inactivity towards the local community when they worked abroad. The money they earned during emigration gives them confidence and financial stability, thanks to which they do not have to focus only on work in order to provide themselves and their family with adequate living conditions but can also take actions for their local community.

Attention should also be paid to the increase in spatial mobility in the regions concerned. This means that people who already have a lot of migration experience will be joined by others. For them, migratory social capital will still be an important resource. Therefore, access to migratory social capital ceases to differentiate migratory behaviours, but only within groups that have significant migratory experiences, such as the inhabitants of Podlasie and the autochthonous population of the Opole region. On the other hand, for the incoming population leaving the Opole region, it will still be an important resource, influencing migratory behaviours. In the case of Opole region, it may prove important to have a progressive differentiation of migrants' nationalities in the situation of popularisation of foreign trips among the migrant population. As regards the autochthonous population, it was clear that strong ethnic links had developed due to mobility. International labour migrations contributed to the creation of strong bonding capital in this group. The question whether similar mechanisms will occur in the group of migrants of immigrant origin remains open. Similarly, it is worth considering to what extent the dissemination of migration among the population of immigrant origin will influence the establishment of inter-ethnic migration networks and bridging social capital. It can be assumed that migrants from this group will try to base their efforts on the experiences and connections created over the years by which in turn may lead to the rapprochement of both communities. Analysing the existing social capital resources of the incoming inhabitants of the Opole region and the specificity of the local migration, I believe, however, that none of the above-mentioned positive phenomena will take place, and additionally, the trips may contribute to further erosion of the already low level of social capital. Up to now, in the case of the Opolskie voivodeship, most of the trips were temporary migration. As the number of migrants of influx origin increases, this trend is likely to come to an end. This may lead (as in the case of Podlasie) to weakening of bonds connecting migrants with persons who remained in their places of origin and thus have a negative impact on the quality of social capital. I think that, nowadays, in the case of intra-European migration, traditional, especially illegal institutions educated by migrants, will lose their importance. In this case, the social capital of migrants will be replaced by human capital or legal organisational and legal solutions. 
Open Access This article is licensed under a Creative Commons Attribution 4.0 International License, which permits use, sharing, adaptation, distribution and reproduction in any medium or format, as long as you give appropriate credit to the original author(s) and the source, provide a link to the Creative Commons licence, and indicate if changes were made. The images or other third party material in this article are included in the article's Creative Commons licence, unless indicated otherwise in a credit line to the material. If material is not included in the article's Creative Commons licence and your intended use is not permitted by statutory regulation or exceeds the permitted use, you will need to obtain permission directly from the copyright holder. To view a copy of this licence, visit http://creativecommons.org/licenses/by/4.0/.

\section{References}

Baron, S., Field, J., \& Schuller, T. (2000). Social capital: critical perspectives. Oxford: Oxford University Press.

Chałasiński, J. (1904-1979)(1936). Emigracja jako zjawisko społeczne. Przeglad Socjologiczny. Warszawa, IV (3-4), 495-501.

D’Ambrosio, A., Montresor, S., Parrilli, M. D., \& Quatraro, F. (2019). Migration, communities on the move and international innovation networks: an empirical analysis of Spanish regions. Regional Studies. Routledge, 53(1), 6-16. https://doi.org/10.1080/00343404.2018.1426850.

Edwards, B., Foley, M. W., \& Diani, M. (2001). Beyond Tocqueville: civil society and the social capital debate in comparative perspective. Hanover, London: University Press of New England.

Eisenstadt, S. N. (1953). Analysis of patterns of immigration and absorption of immigrants. Population Studies, 7(2), 167. https://doi.org/10.2307/2172030.

Faist, T. (1997). From common questions to common concepts. In T. Hammar et al. (Eds.), International migration, immobility and development: multidisciplinary perspectives (pp. 247-276). Oxford: Berg Available at: https://pub.uni-bielefeld.de/record/2466660 (Accessed: 9 January 2020).

Faist, T. (2000). The volume and dynamics of international migration and transnational social spaces. Oxford, New York: Clarendon Press.

Fischer, P. et al. (1998) Why do people stay? the insider advantages approach: empirical evidence from Swedish labour markets, CEPR Discussion Papers. C.E.P.R. Discussion Papers. Available at: https://ideas.repec.org/p/cpr/ceprdp/1952.html (Accessed: 25 August 2018).

Garip, F. (2008). Social capital and migration: how do similar resources lead to divergent outcomes? Demography, 45(3), 591-617. https://doi.org/10.1353/dem.0.0016.

Glorius, B. (2019). Transnational social capital in migration: the example of student migration from Bulgaria to Germany. Social Inclusion. Cogitatio Press, 7(4), 232-242. https://doi.org/10.17645/si.v7i4.2390.

Główny Urząd Statystyczny. (2015). Mały Rocznik Statystyczny Polski 2015. Warszawa: Główny Urząd Statystyczny.

Główny Urząd Statystyczny (2019) Informacja o rozmiarach i kierunkach czasowej emigracji z Polski w latach 2004-2018. Warszawa. Available at: https://stat.gov.pl/download/gfx/portalinformacyjny/pl/defaultaktualnosci/5471 /2/12/1/informacja_o_rozmiarach_i_kierunkach_czasowej_emigracji_z_polski_w_latach_2004-2018.pdf (Accessed: 27 March 2020).

Guilmoto, C. and Sandron, F. (2001) The internal dynamics of migration networks in developing countries. Available at: http://horizon.documentation.ird.fr/exl-doc/pleins_textes/divers17-02/010047710.pdf (Accessed: 24 August 2018).

Hirszfeld, Z., \& Kaczmarczyk, P. (2000). In ISS UW (Ed.), Współczesne migracje zagraniczne ludności Podlasia. Warszawa: ISS UW.

Hotchkiss, J. L., \& Rupasingha, A. (2018). Individual social capital and migration, Working Papers. Center for Economic Studies, U.S. Census Bureau. Available at: https://ideas.repec.org/p/cen/wpaper/18-14. html. Accessed 24 Aug 2020.

Koltai, J., Sik, E., \& Simonovits, B. (2020). Network capital and migration potential. International Journal of Sociology. Routledge, 50(2), 122-141. https://doi.org/10.1080/00207659.2020.1726110.

Łukaszewska-Bezulska, J. (2014) Social capital and migrations: an analysis of interactions in light of particular theoretical concepts - Problemy Polityki Społecznej - Numer nr 4 (2014) - BazEkon - Yadda, Problemy Polityki Społecznej. Studia i Dyskusje, 27(4), pp. 23-40. Available at: http://www. problemypolitykispolecznej.pl/images/czasopisma/27/PPS-27-23-40.pdf (Accessed: 9 January 2020). 
Massey, D. S. (1999) Why does immigration occur?, In Hirschman, C., Kasinitz, P., and DeWind, J. (eds) The handbook of international migration. Russell Sage Foundation (The American Experience), pp. 34-52. Available at: http://www.jstor.org/stable/10.7758/9781610442893.9. Accessed 24 Aug 2018.

Massey, D. S., \& Zenteno, R. M. (1999). The dynamics of mass migration. Proceedings of the National Academy of Sciences of the United States of America. National Academy of Sciences of the United States of America, 96(9), 5328 Available at: http://han.buw.uw.edu.pl/han/Ebsco/search.ebscohost.com/login. aspx?direct=true \&db=edsjsr\&AN=edsjsr.47395\&lang=pl\&site=eds-live \&scope=site. Accessed 24 Aug 2018.

Massey, D. S., et al. (1993). Theories of international migration: a review and appraisal. Population and Development Review, 19(3), 431. https://doi.org/10.2307/2938462.

Merton, R. K. (1968). The Matthew effect in science. Science. American Association for the Advancement of Science, 56-63. https://doi.org/10.2307/1723414.

Nowotny, K., \& Pennerstorfer, D. (2019). Network migration: do neighbouring regions matter? Regional Studies. Routledge, 53(1), 107-117. https://doi.org/10.1080/00343404.2017.1380305.

Ostrom, E. (1990). Governing the commons: the evolution of institutions for collective action. Cambridge: Cambridge University Press.

du Plooy, D. R., Lyons, A., \& Kashima, E. S. (2020). Social capital and the well-being of migrants to Australia: exploring the role of generalised trust and social network resources. International Journal of Intercultural Relations. Elsevier Ltd, 79, 1-12. https://doi.org/10.1016/j.ijintrel.2020.07.001.

Putnam, R. D. (2008). Samotna gra $w$ kręgle: upadek $i$ odrodzenie wspólnot lokalnych $w$ Stanach Zjednoczonych. Warszawa: Wydawnictwa Akademickie i Profesjonalne.

Putnam, R. D., Leonardi, R., \& Nanetti, R. (1993). Making democracy work: civic traditions in modern Italy. Princeton, New York: Princeton University Press.

Rey, A., Rivera-Navarro, J., \& Paniagua de la Iglesia, T. (2019). "Migrant capital” and domestic work: labour trajectories of immigrant women in Spain. International Migration. Blackwell Publishing Ltd, 57(3), 155170. https://doi.org/10.1111/imig.12573.

Sztompka, P. (2007). Zaufanie: fundament społeczeństwa. Kraków: Wydawnictwo Znak.

Urząd Statystyczny w Białymstoku. (2013). Ludność w województwie podlaskim. Stan i struktura społecznodemograficzna. Narodowy Spis Powszechny Ludności i Mieszkań 2011. Białystok: Urząd Statystyczny w Białymstoku.

Urząd Statystyczny w Białymstoku. (2015). Rocznik Statystyczny Wojewodztwa Podlaskiego. Białystok: Urząd Statystyczny w Białymstoku.

Urząd Statystyczny w Opolu. (2013). Ludność w województwie opolskim. Stan i struktura demograficznospołeczna - Narodowy Spis Powszechny Ludności i Mieszkań 2011. Opole: Urząd Statystyczny w Opolu.

Wahlbeck, O., \& Fortelius, S. (2019). The utilisation of migrant capital to access the labour market: the case of Swedish migrants in Helsinki. Social Inclusion. Cogitatio Press, 7(4), 181-189. https://doi.org/10.17645 /si.v7i4.2325.

White, A., et al. (2018). The impact of migration on Poland. The impact of migration on Poland. UCL Press. https://doi.org/10.2307/j.ctv550d7m.

Publisher's Note Springer Nature remains neutral with regard to jurisdictional claims in published maps and institutional affiliations. 